\title{
Argentaffine Cells in the Digestive Tract of Hibernating and Non-hibernating in Chinese Fire-bellied Newt (Cynops orientalis)
}

\author{
Celulas Argentafines en el Tracto Digestivo del Tritón de Vientre de Fuego Chino \\ (Cynops orientalis) en Periódos de Hibernación y No Hibernación
}

"Zhaohui Xie; "Duanqiang Guo; ** Chengkai Lu; "Boying Li \& *Linna Shan

XIE, Z.; GUO, D.; LU, C.; LI, B. \& SHAN, L. Argentaffine cells in the digestive tract of hibernating and non-hibernating in Chinese fire-bellied newt (Cynops orientalis). Int. J. Morphol., 30(4):1389-1394, 2012.

SUMMARY: In order to further studying the relationship between the gastrointestinal endocrine cells and the hibernation of Chinese fire-bellied newt, histological techniques were used in this study to explore the distributed density and morphology of argentaffine cells in the digestive tract during hibernation and non-hibernation. The argentaffine cells could be observed throughout the digestive tract of Chinese fire-bellied newt during hibernation and non-hibernation and mainly distributed in the acinar epithelial cells, epithelial cells and intrinsic membrane. They had appeared in the shape of goblet, pyramid, ellipse, round, cone-shaped, spindle-shaped. The cytoplasm contains secretory granules at the basal regions with spherical nuclei in the basal regions. Most of them had processes in different directions, suggesting that the argentaffine cells have combined the function of endocrine and exocrine. The distribution density curves of argentaffine cells were generally wavelike during the two periods. It was highest in the body of stomach in hibernation, while in nonhibernation it was highest in the pyloric. Totally the density of argentaffine cells was higher in hibernation period than that in nonhibernation period. The results showed that the activity of the digestive tract was expectedly weakened during the hibernation, but the function of endocrine was actually strengthened.

KEY WORDS: Cynops orientalis; Digestive tract; Argentaffine cells; Hibernation.

\section{INTRODUCTION}

Chinese fire-bellied newt (Cynops orientalis, David, 1873) belongs to Amphibian, Caudata, Salamandridae in classification is a local species of China. It has a high value in researching and occupies an important position in evolutionary biology and developmental biology. Digestive tract, the largest endocrine organ in the body, is a continuous pipeline starting from mouth cavity to anus, secreting the most endocrine products which were considered as the general messengers among the cells in the body (Rehfeld, 1998; Ahlman \& Nilsson, 2001). Large types and quantities of endocrine cells in the gastrointestinal epithelia of the digestive tract secreting a variety of biological active substances which play important regulatory roles in digestion organs or tissues (Solcia et al., 1981). Argentaffine cell, a kind of secretory cells, is widely distributed in the digestive tract (Josephson \& Altmann, 1973), belonging to the APUD (amine precursor uptake and decarboxylation, APUD) system. Its main secretion, 5-hydroxytryptamine (5-HT), has a strong function in the regulation of digestive by stimulating vascular contractions of smooth muscle and vasodilatations (Lange, 1973; Solcia et al., 1975; El-Salhy \& Lundquvis, 1985; Arena et al., 1990). At present, many scholars have investigated the argentaffine cells in the digestive tract in fishes, amphibians, reptiles and mammals (El-Salhy \& Lundquvis; Patent \& Epple, 1967; Carvalheira et al., 1968; Perez-Tomas et al., 1989; Arena et al.; D'Este et al., 1994), moreover, they have studied the gastrointestinal endocrine cells by immunohistochemical methods and medical experiments (Eissele et al., 1997; Scillitani et al., 2008). There were littlefocused on argentaffine cells in Chinese fire-bellied newt.

In this paper, we observed the argentaffine cells in digestive tract compared statistically the density in Chinese fire-bellied newt during the hibernation and non-hibernation. Our aim is to explore the adaptability on seasonal changes to environment in the Chinese fire-bellied newt.

\footnotetext{
* Department of Bioengineering, Henan University of Urban Construction, Henan, China.

${ }^{* *}$ School of life Sciences, Lanzhou University, Lanzhou, China.
} 


\section{MATERIAL AND METHOD}

Specimens and sections. The animals used in this experiment were 20 females and 15 males (total length $40.1 \pm 2.0 \mathrm{~mm}$, weight $1.90 \pm 0.33 \mathrm{~g}$ ) were captured separately in Dec 2009 and May 2010 in Guangshui, Hubei. China. Injected 5\% sodium pentobarbital into the Chinese fire-bellied newt's abdominal cavity to make it narcosised, then damaged the nerve center to death, opened the coelom and got the integral alimentary canal out, afterwards, take the esophagus, stomachus, cardiacus, body of stomach, stomachus pyloricus, duodenum, ileum, rectum out respectively, flushed all of them using physiological saline at once and fixed Bouin's fluid for $24 \mathrm{~h}$. After being dehydrated through an ethanol-xylene series the specimens were embedded in paraffin. Sections were cut at $6 \mathrm{~mm}$ thichness and mounted on gelation-coated slides.

Histochemical staining. The section was then stained by an Grumelius method described elsewhere (Grimelius \& Wilander, 1980) Each representative section was deparaffinized and transfered to distilled water, leave in $0.5 \%$
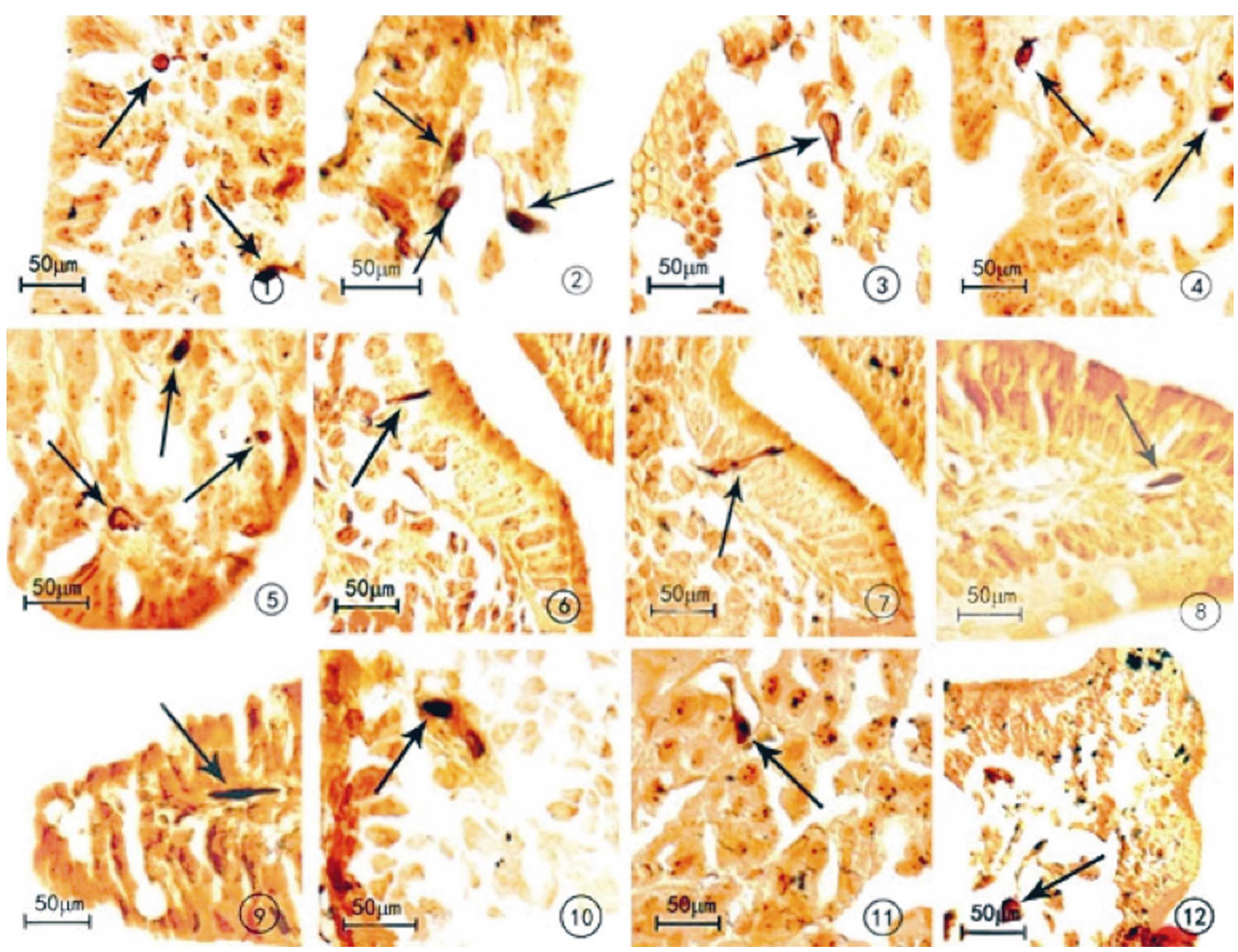

silver nitrate solution for 2 hours at $60^{\circ} \mathrm{C}$. Rinse in distilled water, then treated in Bodian developer (hydroquinone, $1 \mathrm{~g}$; sodium sulphite, $5 \mathrm{~g}$; distilled water, $100 \mathrm{ml}$ ) previously heated to $60^{\circ} \mathrm{C}$.Rinse in running tap water, distilled water, and then re-impregnate for 10 minutes at $60^{\circ} \mathrm{C}$ in the same silver solution and reduce in Bodian's solution. The argentaffine cells were colored dark brown or black and background yellow.

Observation, photomicrograph and cell count. All specimens were observed and photomicrographed under Nikon TE2000-U photomicroscope. The argentaffine cells on sections were counted under stereo frame was set to 200 x $200 \mu \mathrm{m}$ field. The average number of argentaffine cells from 10 fields selected randomly in each specimen. Then the average number of the argentaffine area cells within the frame and calculated the density.

Statistical analysis. Data were expressed as mean $\mathrm{X} \pm \mathrm{SD}$ and variance analysis was performed using SPSS 13.0 software. One-way analysis of variance was used for multiple comparisons, and Duncan's test was used for intra-group comparisons. $\mathrm{P}<0.05$ was considered statistically significant. 


\section{RESULTS}

Argentaffine cells were detected throughout the entire digest tract of Chinese fire-bellied newt distributed in the acinar epithelial cells, epithelial cells and intrinsic membrane. They had appeared in the shape of goblet, pyramid, ellipse, round, cone-shaped, spindle-shaped. The cytoplasm contains secretory granules at the basal regions with spherical nuclei in the basal regions. The morphological argentaffine cells
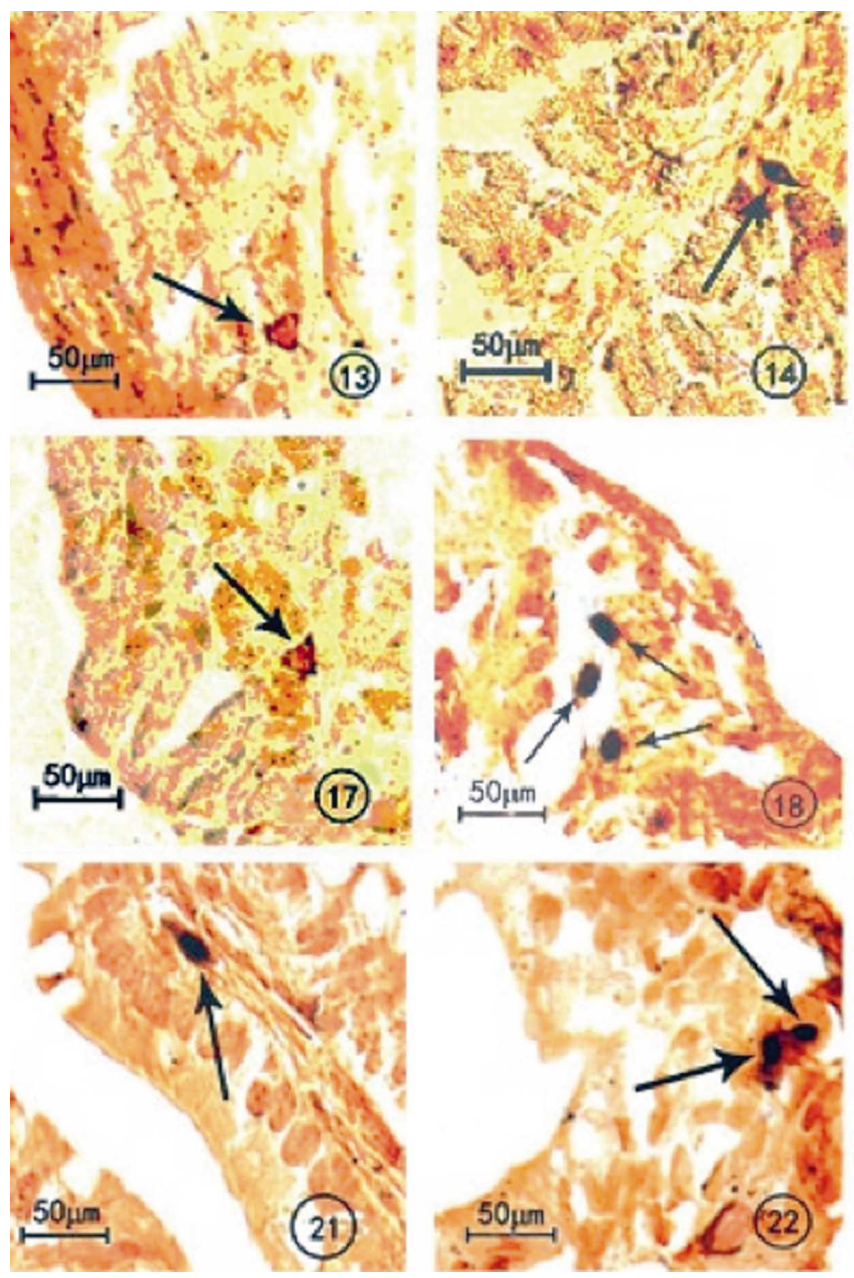

Fig. 1. Round and cone-shaped argentaffine cells in esophagus during hibernation ( $\uparrow$ ). Fig. 2. Ellipse argentaffine cells in cardia during hibernation ( $\uparrow$. Fig. 3. Cone-shaped argentaffine cells in cardia during hibernation ( $\uparrow$ ). Fig. 4. Ellipse and cone-shaped argentaffine cells in stomach during hibernation ( $\uparrow$ ). Fig. 5. Round and ellipse argentaffine cells between gastric acinar epithelial cells during hibernation ( $\uparrow$ ). Fig. 6. Spindle-shaped argentaffine cells between epithelial cells of pylorus during hibernation ( $\uparrow$ ). Fig. 7. Spindle-shaped argentaffine cells between epithelial cells of pylorus during hibernation ( $\uparrow$ ). Fig. 8. Spindle-shaped argentaffine cells between epithelial cells of duodenum during hibernation ( $\uparrow$ ). Fig. 9 . Spindle-shaped argentaffine cells in duodenum during hibernation ( $\uparrow$ ). Fig. 10. Ellipse argentaffine cells in ileum during hibernation ( $\uparrow$ ). Fig. 11. Cone-shaped argentaffine cells in ileum during hibernation ( $\uparrow$ ). Fig. 12. Round argentaffine cells in rectum during hibernation ( $\uparrow$ ). Fig. 13. Coneshaped argentaffine cells between esophageal epithelial cells during non-hibernation ( $\uparrow$ ). Fig. 14. Cone-shaped argentaffine cells in esophagus during non-hibernation ( $\uparrow$ ). Fig. 15. Ellipse argentaffine cells between cardiaic epithelial cells during non-hibernation $(\uparrow)$. Fig. 16. Spindleshaped argentaffine cells in stomach during non-hibernation $(\uparrow)$. Fig. 17. Cone-shaped argentaffine cells between gastric acinar epithelial cells during non-hibernation $(\uparrow)$. Fig. 18. Ellipse argentaffine cells in pylorus during non-hibernation $(\neq)$. Fig. 19. Ellipse argentaffine cells between pyloric acinar epithelial cells during non-hibernation ( $\uparrow$ ). Fig. 20. Spindle-shaped argentaffine cells in duodenum during non-hibernation ( $\uparrow$ ). Fig. 21. Ellipse argentaffine cell in duodenum during non-hibernation ( $\uparrow$ ). Fig. 22. Ellipse argentaffine cell in ileum during non-hibernation ( $\uparrow$ ). Fig. 23. Ellipse argentaffine cell in ileum during non-hibernation ( $\uparrow$ ). Fig. 24. Ellipse argentaffine cell in rectum during non-hibernation ( $\uparrow$ ). 
Argentaffine cells were distributed in the digestive tract during both hibernation and nonhibernation. It mainly distributed between the mucosal epithelial cells and acinar epithelial cells, but the density in each section of digestive tract was not the same (Fig. 25; Table I). In addition, the density on the same part during different periods also had differences distributed. Density curves of the argentaffine cells in hibernation and non-hibernation were generally wavilness. The peak of the distribution was in the body of stomach during hibernation, while it was in the pyloricus during nonhibernation. Totally, the density of argentaffine cells was higher in hibernation period than that in non-hibernation period.

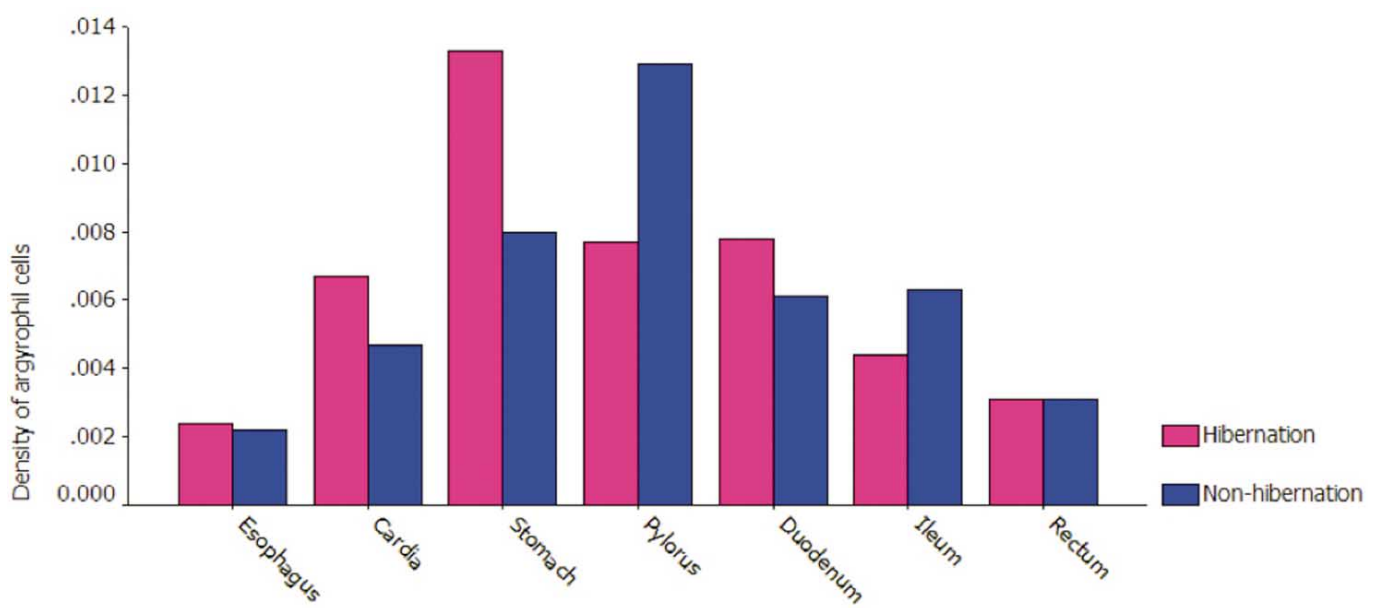

Fig. 25. Distribution of argentaffine cells of different parts in the digestive tract during hibernation and nonhibernation.

\section{DISCUSSION}

The findings of the present investigation show that the configuration and distribution of argentaffine cells in digestive tract of Chinese fire-bellied newt during hibernation and nonhibernation. The distributed densities of the argentaffine cells are related to their position and secreting secretion of argentaffine granules. The peak of the density of argentaffine cells of Chinese fire-bellied newt are populated in pyloric stomach during hibernation and in pylorus during non-hibernation. The distribution density curves during these two periods are generally wavelike. This phenomenon is similar to Rana amurensis (Liu et al., 2010). The peak of the distributed density of the argentaffine cells is not the same in different animals, the pyloric stomach in Bufo gargarizans (Chu \& Deng, 2002), Pelophylax nigromaculata (Zhao \& Li, 2003) and Hynobius leechi (Ren et al., 2011); duodenum in Alligator sinensis (Zhang et al., 1999); and rectum in Salamandrella keyserlingii (Ren et al.). As Chu \& Deng (2004) indicated that the density of argentaffine cells has a positive correlation with muscular layer of digest wall and the density of mucous gland. It is high density that the argentaffine cells in cardia, stomach and pylorus on which have well-development in the digest tract.

Various endocrine cells distributed in the gastrointestinal epithelium and glands, in which the secretory granules mainly crowded at the basal part of the cells (Nilsson et al., 1987), so they also called basal granular cells. This type of cells is not easy to identify by H-E staining, but they are available with chrome or silver staining, so silver staining method was used in this experiment. Argentaffine cells is a type of gastrointestinal endocrine cells mainly secrete 5-HT which is an important neurotransmitter and modulator in the body, stimulating mucous secretion, intrinsic and extrinsic nerves, and vascular expansion, associated with digestion (Solcia et al., 1975; El-Salhy \& Lundquvis; Nozawa et al., 2009). Further physiological studies are required to elucidate the ways in which the distribution of gastrointestinal endocrine cells may be related to regulatory characteristics of the digest tract. 
Gastrointestinal endocrine cells not only have endocrine function, but also have the exocrine and paracrine effect (Bülbring \& Crema, 1959; Håkanson, et al., 1971; Uvnäs-Wallensten \& Rehfeld, 1976). In this paper, the argentaffine cells could be observed in the intrinsic membrane, or their protrusions extended into the intrinsic membrane and a lot of secretory granules was obvious around the protrusions, these morphologic basis proved that the sections of argentaffine cells can get though the intrinsic membrane and then into the blood circulation to exercise its function, thus confirmed the endocrine function of argentaffine cells. Moreover, argentaffine cells generally exited between mucosal epithelial cells in the digestive tract, some protrusions of argentaffine cells extending into the digestive cavity, and occasionally argentaffine grains and argentaffine cells connected together, indicating the exocrine function of argentaffine cells. A certain amount of spindleshaped argentaffine cells were found in this experiment, one end of them reached into to the digestive cavity, the other one reached into intrinsic membrane, suggesting these argentaffine cells may have both endocrine function and exocrine function. This paper revealed no morphological basis of the paracrine function of argentaffine cells.

The purpose of hibernation of animals is to make sure that they can survive in low temperature environment. Hibernant lowers animal metabolism and store energy in the body to sustain life (Cushing \& Goetsch, 1915; Storey \& Storey, 2004). We found that the distributed peak of the argentaffine cells was in the body of stomach by statistical analysis. In order to maintain the provision of energy, more secretions should be produced by stomach to fully digest the food, facilitate absorption better. The argentaffine cells is mainly distributed in the pylorus indicate that food processing, pyloric secretions can stimulate the secretion of gastric acid, which can decompose the connective tissues and muscle fibers in the food to make the protein of the food denaturation, suggesting that endorcinic function of the digestive tract in more reserved in hibernation period. The distributed densities of the argentaffine cells in the rectum during hibernation and non-hibernation were generally the same, this may because of that the rectum located at the end of the digestive tract connecting with urogenital tract directly, rarely participated in digest function, and its structure is different from the gastrointestine of anura. We deduce that the rectum and hibernate do not have a direct relationship. The distribution, density and configuration of the argentaffine cells in digestive tract in hibernation period is similar to that in non-hibernation period, but the density of argentaffine cells and the density of argentaffine granuals in the argentaffine cells are higher in hibernation period than in non-hivernation period. Those common traits may reflect the adaptability on seasonal changes to environment in the Chinese fire-bellied newt.

XIE, Z.; GUO, D.; LU, C.; LI, B. \& SHAN, L. Células argentafines en el tracto digestivo del tritón de vientre de fuego chino (Cynops orientalis) en periódos de hibernación y no hibernación. Int. J. Morphol., 30(4):1389-1394, 2012.

RESUMEN: Con el fin de promover el estudio de la relación entre las células endocrinas gastrointestinales y la hibernación del tritón vientre de fuego chino, fueron utilizados técnicas histológicas para explorar la densidad de distribuición y la morfología de las células argentafines en el tracto digestivo durante la hibernación y la no hibernación. Las células argentafines pudieron ser observadas en todo el tracto digestivo de tritón vientre de fuego chino durante la hibernación y no hibernación, y se distribuyeron principalmente en las células epiteliales acinares, células epiteliales y la membrana intrínseca. Aparecieron de forma caliciforme, piramidal, elíptica, redonda, cónica y de huso. El citoplasma contenía gránulos de secreción en las regiones basales con núcleos esféricos en esa región. La mayoría de ellos tenía procesos en diferentes direcciones, lo que sugiere que las células argentafines combinaron la función del sistema endocrino y exocrino. Las curvas de densidad de distribución de las células argentafines fueron generalmente ondulante durante los dos períodos. Esta fue más alta en el cuerpo del estómago en estado de hibernación, mientras que en la no hibernación fue mayor en el píloro. En total, la densidad de las células argentafines era mayor en el periodo de hibernación. Los resultados mostraron que la actividad del tracto digestivo se debilitó, como era de esperar, durante la hibernación, pero la función del sistema endocrino se fortaleció.

PALABRAS CLAVE: Cynops orientalis; Tracto digestivo; Células argentafines; Hibernación.

\section{REFERENCES}

Ahlman, H. \& Nilsson, O. The gut as the largest endocrine organ in the body. Ann. Oncol., 12(Suppl. 2):63-8, 2001.

Arena, P. C.; Richardson, K. C. \& Yamada, J. Animmunohistochemical study of endocrine cells of the alimentary tract of the King's skink (Egernia kingii). J. Anat., 170:73-85, 1990.
Bülbring, E. \& Crema. A. The action of 5-hydroxytryptamine, 5hydroxytryptophan and reserpine on intestinal peristalsis in anaesthetized guinea-pigs. J. Physiol., 146(1):29-53, 1959.

Carvalheira, A. F.; Welsch, U. \& Pearse, A. G. Cytochemical and ultrastructural observations on the argentaffin and argentaffine cells of the gastro-intestinal tract in mammals, and their 
place in the APUD series of polypeptide-secreting cells. Histochemie, 14(1):33-46, 1968.

Chu, D. C. \& Deng, Z. X. Argentaffine cells in digestive tract of hibernating and non-hibernating Bufo gargarizans and Pelophylax migromaculata. Chinese J. Anat., 39(1):21-4, 2004.

Chu, D. C. \& Deng, Z. X. Configuration and distribution of digestive tube argentaffine cell of Bufo bufo gargarizans. Chinese J. Anat., 25(3):289-92, 2002.

Cushing, H. \& Goetsch, E. Hibernation and the pituitary body. $J$. Exp. Med., 22(1):25-47, 1915.

D'Este, L.; Buffa, R.; Pelagi, M.; Siccardi, A. G. \& Renda, T. Immunohistochemical localization of chromogranin $\mathrm{A}$ and $\mathrm{B}$ in the endocrine cells of the alimentary tract of the green frog, Rana esculenta. Cell Tissue Res., 277(2):341-9, 1994.

Eissele, R.; Brunner, G.; Simon, B.; Solcia, E. \& Arnold, R. Gastric mucosa during treatment with lansoprazole: helicobacter pylori is a risk factor for argyrophil cell hyperplasia. Gastroenterology, 112(3):707-17, 1997.

El-Salhy, M. E. \& Lundquvis, W. N. Comparative studies of serotoninlike immunoreative cells in the digestive tract of vertebrates. Biom. Res., 6(6):371-5, 1985.

Grimelius, L. \& Wilander, E. Silver stains in the study of endocrine cells of the gut and pancreas. Invest. Cell Pathol., 3(1):3-12, 1980.

Håkanson, R.; Owman C.; Sporrong, B. \& Sundler, F. Electron microscopic identification of the histamine-storing argyrophil (enterochromaffin-like) cells in the rat stomach. Cell Tissue Res., 122(4):460-6, 1971.

Josephson, R. L. \& Altmann G. G. Distribution of diazo-positive (argentaffin) cells in small intestine of rats of various ages. Am. J. Anat., 136(1):15-22, 1973.

Nozawa, K.; Kawabata-Shoda, E.; Doihara, H.; Kojima, R.; Okada, H.; Mochizuki, S.; Sano, Y.; Inamura, K.; Matsushime, H.; Koizumi, T.; Yokoyama, T. \& Ito, H. TRPA1 regulates gastrointestinal motility through serotonin release from enterochromaffin cells. Proc. Natl. Acad. Sci. USA, 106(9):3408-13, 2009.

Lange, E. Carcinoid-like tumours in the pseudobranch of Gadus morhua L. Comp. Biochem. Physiol. A Comp. Physiol., 45(2):477-88, 1973 .

Liu, C.; Lu, X. H.; Li, S. L. \& Zhao, W. G. Comparative research of argentaffine cells in the digestive tract of Rana amurensis during pre-hibernation, hibernation and post-hibernation. Chinese J. Anat., 33(4):455-7, 2010.

Nilsson, O.; Ahlman, H.; Geffard, M.; Dahlström, A. \& Ericson, L. E. Bipolarity of duodenal enterochromaffin cells in the rat. Cell Tissue Res., 248(1):49-54, 1987.
Patent, G. J. \& Epple, A. On the occurrence of two types of argyrophil cells in the pancreatic islets of the holocephalan fish, Hydrolagus colliei. Gen. Comp. Endocrinol., 9(3):32530, 1967.

Perez-Tomas, R.; Ballesta, J.; Pastor, L. M.; Madrid, J. F. \& Polak, J. M. Comparative immuno- histochemical study of the gastroenteropancreatic endocrine system of three reptiles. Gen. Comp Endocrinol., 76(2):171-91, 1989.

Rehfeld, J. F. The new biology of gastrointestinal hormones. Physiol. Rev., 78(4):1087-108, 1998.

Ren, C. Y.; Cao L.; Li, S. L. \& Zhao, W. G. Comparison of Argyrophil Cells in Digestive Tract of Salamandrella keyserlingii and Hynobius leechii. Chinese Agric. Sci. Bull., 27(11):46-9, 2011.

Scillitani, G.; Liquori, G. E.; Mastrodonato, M. \& Ferri, D. Histochemical and immunohistochemical characterization of exocrine cells in the foregut of the red-eared slider turtle, trachemys scripta (Emydidae). Arch. Histol. Cytol., 71(5):27990, 2008.

Solcia, E.; Capella, C.; Vassallo, G. \& Buffa, R. Endocrine cells of the gastric mucosa. Int. Rev. Cytol., 42:223-86, 1975.

Solcia, E.; Polak, J. M.; Larsson, L. I.; Buchan, A. M. S. \& Capeela, C. Update on Lausanne classification of endocrine cells. 2nd ed. In: Bloom, S. R. \& Polak, J. M. (Eds.). Gut Hormones. Edinburgh, Churchill Livingstone, 1981. pp.96-100.

Storey, K. B. \& Storey, J. M. Metabolic rate depression in animals: transcriptional and translational controls. Biol. Rev. Camb. Philos. Soc., 79(1):207-33, 2004.

Uvnäs-Wallensten, K. \& Rehfeld, J. F. Molecular forms of gastrin in antral mucosa, plasma and gastric juice during vagal stimulation of anesthetized cats. Acta Physiol. Scand., 98(2):217-26, 1976.

Zhang, S. Z.; Wu, X. B.; Chen, B. H.; Wang, R. P.; Wang, C. L. \& Xie, W. S. Distribution and Morphologic Observation of Argyrophil Cells in the Digestive Tract of Alligator Sinensis. Chinese J. Zool., 34(3):31-5, 1999.

Zhao, W. Y. \& Li, S. L. Distribution and morphologic observation of argyrophil cells in intestines and stomach of Pelophylax nigromaculata. Chinese J. Comp. Med., 13(6):364-7, 2003.

\section{Correspondence to: \\ Linna Shan \\ Department of Bioengineering \\ Henan University of Urban Construction \\ Mingyue Road, New zone Pingdingshan \\ Henan, 467000 \\ CHINA}

Received: 02-05-2012

Email: linnashan@QQ.com

Accepted: 17-08-2012 